\title{
The Influence of Organizational Commitment, Competence of Village Fund Management Offficers, and Utilization of Information Technology on Accountability of Village Financial Management
}

\author{
Siska Apriana A. Mantako ${ }^{{ }^{*}}$, Darwis Said ${ }^{2}$, and Nurleni ${ }^{3}$ \\ 1,2,3 Universitas Hasanuddin, Makassar, Indonesia
}

\begin{abstract}
This study aims to analyze the effect of commitment of organization, competence of village fund management officers, and utilization of information technology on accaountability of village financial management either partially or simultaneously.The data used in the study are primary data in the form of questionnaires with a total sample of 96 respondents. The method used is a quantitative approach and multiple linear regression analysis which determined by purposive sampling method. The findings from this research indicate that (1) partially commitment of organization, competence of village fund management officers and utilization of information technology has a positive effect and significant impact on the accountability of village financial management (2) commitment of organization, competence of village fund management officers and utilization of information technology has simultaneous effect on the accountability of village financial management.
\end{abstract}

Keywords: Accountability of Village Financial Management, Commitment of Organization, Competence of Village Fund Management Offficers, Utilization of Information Technology

\section{Introduction}

Decentralization is a delegation of authority from the central government to local governments. Decentralization aims to allow the government to improve the efficiency and effectiveness of the services for every people (Sakinah, 2013). Decentralization has several aspects; political, administrative, and fiscal decentralization (Putri, 2018). This is merely because the decentralization provides a space for the lower government to conduct the governmental process, which is in accordance with the authority and responsibilities mandated.

In Indonesia one of the decentralization that is being implemented is the delegation of authority from the central government to local governments and village governments. Authority given is a governmental policy which is given autonomously to the village, which is intended to place a foundation for the development to start at the village level. This is clearly seen in the National Medium Term Plan (RPJM) 20152019 which mandates to develop Indonesia from the suburban area and to strengthen the local and village. It is intended to address the problem of poverty and vulnerability due to the inequality of development (Ministry of Villages, Disadvantaged Regions and Transmigration, 2015). This authority is clearly legitimate and followed up by the stipulation of various regulations. One of them is a Regulation of the Minister of Home Affairs No. 20 of 2018 replacing the Regulation No. 113 year 2014 about village financial management, which is intended to help the government to synchronize all programs in the village with the national programs. So, that the development that occurs in the village can run smoothly and according to the national government program.

\footnotetext{
* Corresponding author. Email address : siskaapriana3@gmail.com
} 
Village government is authorized to implement fiscal decentralization. This implementation is applied in village financial management. Village finances are all rights and obligations that can be measured with money and all things in the form of money and goods relating to the implementation of rights and obligations. The village finances are managed on a transparent, accountable, and participatory basis and are conducted with discipline and appropriate budgeting approach. The village's financial management process is planning, implementing, administration, reporting and accountability. In line with the implementation of village autonomy, a good village financial management system is focused on managing the village fund systems in a decentralized manner that is transparent, efficient and accountable to the community.

Accountability is the responsibility of authorized institutions, in this discussion is a village government to manage public resources periodically. The form of accountability of the village is responsible for its financial statements from budget planning, budget usage and full budget reporting. Accountability can be implemented by giving access to stake holders, they are decision-makers and every implementer in various levels, this includes at the program, area and community level. The Financial Audit Board (BPK) in the financial management of the village encourages it to be effective and used according to the village needs. In realizing the principle of accountability in village finance management required a continuous and evaluated stage.

Organizational Commitment is a psychological tool in running an organization to achieve an expected goal. This is a form of village government's commitment to manage the finances of the village so that it can be used effectively and efficiently. The effectiveness of each organization is heavily influenced by human behavior. Accountability in village financial management requires organizational commitment. This is due to the organization having human resources as one of the important elements that support the organization. The performance of organization depends on individual performance, so it takes more than just knowledge.

Research conducted by Mada et al (2017) revealed that the organizational commitment has significant effect on accountability of village funds management. In line with that, research conducted by Putri (2018) revealed that the commitment of the village government organization has significant effect on the accountability of village funds management. In creating accountability of the village's financial management resources that do the responsibility must have adequate ability. Therefore, to achieve the objectives of the Organization, in addition to the organizational commitment, the competence of village personnel in carrying out their duties. Competence is a combination of knowledge, expertise, and the skills required to perform work on the functions or tasks that are employed.

Research conducted by Mada et al (2017) reveals a significant influence on accountability of village funds management. Competence of village apparatus so that the government wheel can run maximum. The more competent the village fund management apparatus is the accountability of village funds. The same is found by Muhammad (2018) with the sample of village government in the district of Salo Kampar District came to the conclusion that the competency significantly affects the village government's accountability in managing the allocation of village funds.

The utilization of information technology in the financial management of villages in East Luwu district using the village's financial application System (Siskeudes) version 2.0. The implementation of this application is expected to be more independent village government in managing all the potential and resources owned and the role of very large village that accompanied with responsibility. In addition, financial supervision and inspection processes can be simpler and there are no programs, plans, and reports that do not comply with the prevailing regulations. The results of the study by Putri (2018) revealed that the utilization of information technology significantly affects the accountability of village funds management. This is due to the increasing number of village funds annually. 
The Influence of Organizational Commitment, Competence of Village Fund Management Offficers, and Utilization of Information Technology on Accountability of Village Financial Management

State Financial Accountability Board (BAKN) of the DPR RI in a discussion of legislation forum about "The synergy of Reports between the House of Representatives (DPR) and the The Financial Audit Board (BPK) about 2014-2018 Village Fund and LKPP?" asked the government to evaluate the village fund governance by applying transparency and accountability principles, and promoting the development and supervision of village funds. This is done, considering the increasing trend of village funds every year, but the governance, monitoring and supervision related to the village fund is still problematic. Based on the test results conducted by the Financial Audit Board of the National Government financial statement (LKPP) year 2018, the Financial Audit Board found the absence of surveillance system on the management of village funds. The problems related to the supervision of village funds, among others, the lack of design of surveillance systems and application systems to monitor the management of village funds by the Ministry of Home Affairs, government accounting standards that have not been established, as well as village owned enterprises (BUMDes) that have not contributed significantly to the village economy. The Financial Audit Board conducts the district/City examination which means inspection throughout the village but through random sampling.

\section{Literature Study}

The Stewardship theory explains the form of leadership patterns and superiors ' relationships with their subordinates in an organization using situational mechanisms. The mechanisms consist of management philosophy, organizational culture and leadership to balance personal and organizational goals in order to achieve common goals. The Stewardship theory is used in this research because this theory considers the trust in the village government can be established when it can act according to the interests that exist, which is the public interest in general.

The attribution theory was developed by Fritz Heider who argued that the person's behavior was determined by a combination of internal forces, i.e. factors that came from the inside of a person e.g. ability or effort. External forces, i.e. factors originating from the outside, such as task difficulties or Fortune (Suartana, 2010). There is the term locus of control Internal and locus of control external. Locus Of Control Internal is a feeling that comes from within a person to influence its performance and behavior through its abilities, skills and efforts. Locus Of Control External is a feeling that is controlled by factors that originate from outside the control of a person and the behavior of a person has no influence.

Attribution Theory is used in this research because the village apparatus has a locus of control whether it is factors that originate in itself as well as those outside its control which are certainly different from one another in the management of the village's finances in accordance with the duties and responsibilities relating to the competence of the village government.

Technology Acceptance model (TAM) or technology acceptance model has advantages is a model of Parsimoni is a simple but valid model (Jogiyanto 2007). In Technology Acceptance Model (TAM), ACCEPTANCE of SI usage is influenced by two konstruk, namely usefulness (perceived usefulness) and ease of use (perceived ease of use). Technology Acceptance Model (TAM) is used in this study because it describes the acceptance of information technology that provides the usability and ease of village government in using information technology to manage the village finances in this case the reporting of village funds, which is not a small amount of money.

The organizational commitment consists of two forms of commitment: Attitude commitment (attitudinal commitment) and behavioral commitment. Attitude commitment is the condition or circumstance of an individual considering a personal value and purpose in accordance with the value and purpose of the organization and its willingness to maintain membership in the organization. This attitude approach looks at the organizational commitment as an affective commitment (Allen \& Meyer, 1990) and focuses on the process of how one thinks his relationship to the organization 
(Mowday et al, 1982). The behavioral commitments relate to the extent that the employee sets the decision to be tied to the organization, in case of a loss deciding to do another alternative beyond his current work.

Rudana (2005) explains that competence refers to knowledge, skills and abilities, which can be demonstrated by certain standards. These competencies are demonstrated in the context of work and influenced by organizational culture and work environment. In other words, competence includes a combination of knowledge, expertise, and the necessary skills to perform work or function in the job settings. Airswort, Smith and Millership (2007) said that competence is a combination of job-relevant and skillrelated skills. Competence is a capacity to handle tasks or occupations based on a predefined standard.

Information technology has an important role to use for personal, business, and government purposes. An information technology is strategic information because it is used for decision making for those who utilize such information technology. Information technology uses a set of computers to process data, the desired network system to connect one computer with another and telecommunication technology to disseminate and access globally (Nurillah, 2014). The utilization of information technology is an attitude or behavior of the entity in using information technology to accomplish the task and improve its performance.

Accountability is the control of the government's performance to be accountable to society. Accountability must have a specific procedure about the problems that will be accounted for and decisions to be taken. Accountability can be implemented by giving access to interested parties, which are the decision makers and executor of both programs, regions and communities. Village finances are managed on a transparent, accountable, passive, and orderly basis and budget discipline. The management of the village finances is done within 1 year of the budget from 1 January to 31 December.

The village's financial management is a systematic process carried out by the village apparatus under the prevailing regulations. The village's financial management is based on cash bases. A cash base is a record of transactions when cash is received or issued from a village cash account using the Ministry of Interior managed Information System.

\section{Research framework}

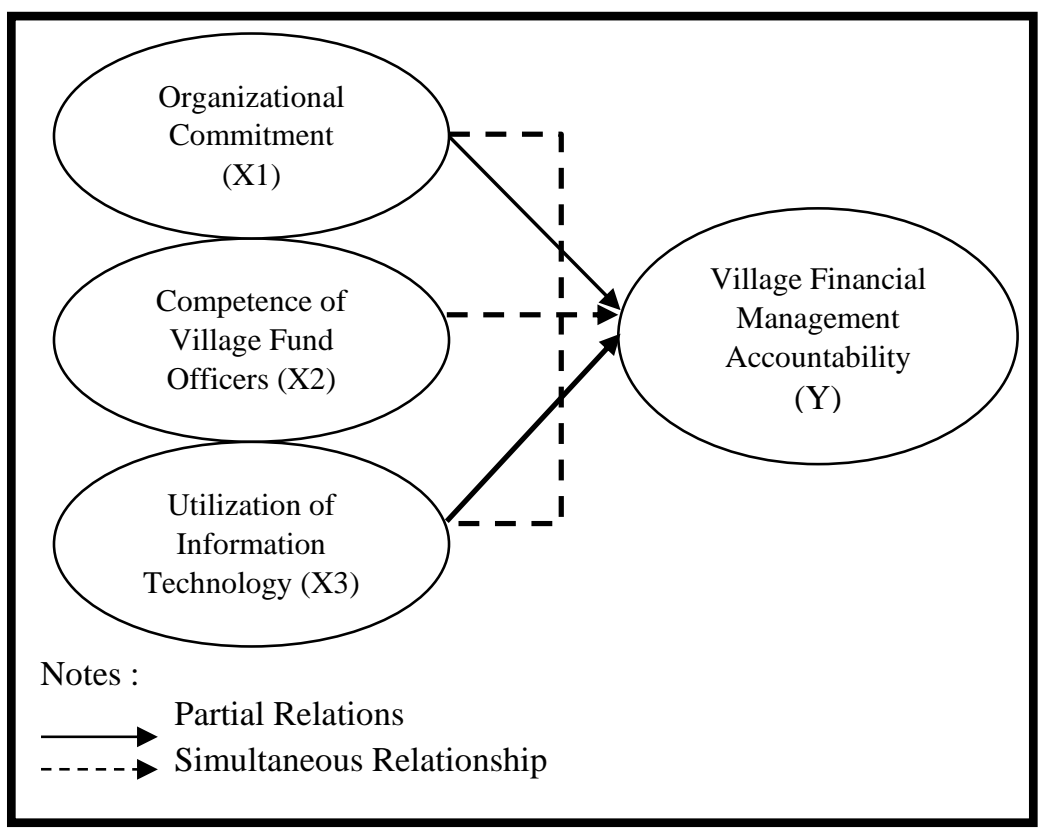

Figure 1 Conceptual Framework 
The Influence of Organizational Commitment, Competence of Village Fund Management Offficers, and Utilization of Information Technology on Accountability of Village Financial Management

\section{Hypothesis}

Based on the theoretical basis and the results of previous studies and the background of the problem described, it can be hypothesized as follows.

$\mathrm{H} 1$ : Influence of organizational commitment to accountability of village financial management.

$\mathrm{H} 2$ : Influence of competency of Village fund management towards accountability of village finance.

H3 : Influence of the utilization of information technology to the accountability of village financial management.

H4 : Influence of organizational commitment, competence of village fund managers, and utilization of information technology to the accountability of village financial management.

\section{Research Methods}

\section{Research plan}

The Study uses quantitative research based on the survey research method which is the research that samples from the population and uses Questionnaire to examine the symptoms of a group or individual behavior by compiling a list of questions and then submitted to the respondent. Independent variables used in this research include organizational commitment, competence of village fund managers, and utilization of information technology while dependent variables are accountability of village financial management. This Study uses primary data in the form of questionnaires distributed to the respondents specified. The type of data used is quantitative data that is of value or score for answers to questions contained in questionnaires.

The population used in this research is comprised of village head, village secretary, Kaur and Kasi elements in 13 villages in Tomoni sub-district, East Tomoni Sub-district and Mangkutana subdistrict. The sampling technique used is the Purposive Sampling Method. Purposive sampling Method is a sampling technique with certain considerations (Sugiyono, 2011). The criteria of researchers as below:

1. PPKD (Village Financial Management Officer)

2. Minimum Employment period of 1 year

3. Level of education minimum SMA/SLTA or equal

4. Villages receiving the village funds

5. A village with an accountability Report

\section{Independent variables \\ Organizational commitments}

Organizational commitment is a psychological tool in running the organization so that it can achieve the goals that Putri expects (2018). The organizational commitments are measured using questions referring to Tyas Research (2014). The indicator for measuring variables in this study is a belief in organizational objectives, the feeling of having an organization, maintaining organizational membership, loyalty within the organization, and a willingness to exert efforts on behalf of the organization.

\section{Competence of Village Fund management}

Competence is generally interpreted as proficiency, skill, ability Muhammad (2018). In performing their job, a person with competence will handle the assignment based on predefined standards. The competence of village fund management personnel is measured using questions referring to Sudiarianti's research (2015). The indicators used to measure variables in this study were the knowledge, ability to improve knowledge, technical expertise, and ability to find solutions, initiative in work. 


\section{Utilization of information technology}

Utilization of good information technology can produce reliable accounting reports. In the financial management of the village, the utilization of information technology has an important role to support the implementation of the Government Accountability Principle of Putri (2018). The utilization of information technology is measured using questions referring to Prelodiarta Research (2015). The indicator for measuring variables in this study is the utilization intensity, frequency of utilization, and number of applications or software used.

\section{Dependent variables}

Village Financial Management Accountability

Accountability is responsible for the management of resources and implementation of policies that have been entrusted to the reporting entity in order to achieve the objectives set periodically (Government accounting standard, 2010). Accountability of village financial management is measured using questions referring to Wardana's research (2016). The indicators for measuring variables in this study are honesty and information disclosure, compliance in reporting, conformity of procedures, adequacy of information, and accuracy of report submission.

\section{Data Analysis Methods}

To analyze data is, testing conducted to measure the validity and reliability of data. Before conducting the hypothesis test, the classic assumption test should be done in advance. The test consists of test normality, multicolinearity test and heterokedastisity test.

\section{Hypothesis Test}

To test the hypothesis using coefficient of determination (R2) test, test $\mathrm{T}$ for partial testing and $\mathrm{F}$ test to simultaneously test all variables independent of the dependent variable.

\section{Results and Discussion}

\section{Research Data Description}

This research uses primary data in the form of questionnaires distributed to village officials in Tomoni sub-district, East Tomoni District, and Mangkutana Subdistrict. Village officials who became respondents in this study amounted to 96 people. The questionnaire consists of 37 question items.

Table 1 Characteristics of Respondents

\begin{tabular}{clcc}
\hline Number & \multicolumn{1}{c}{ Description } & Frequency (Person) & Percentage (\%) \\
\hline 1 & & Gender & \\
& Male & 50 & $53,76 \%$ \\
& Female & 43 & $46,23 \%$ \\
\hline 2 & & Age Group (Years) & \\
& $21-30$ & 37 & $39,78 \%$ \\
& $31-40$ & 32 & $34,40 \%$ \\
& $41-50$ & 17 & $18,27 \%$ \\
& $>50$ & 6 & $6,45 \%$ \\
\hline 3 & & Position & $13,97 \%$ \\
& Village Head & 13 & $13,97 \%$ \\
& Village Secretary & 13 & $13,97 \%$ \\
& Kaur of Finance & 13 & $13,97 \%$ \\
& Kaur of Administration and & 13 & $9,67 \%$ \\
& General Affairs & & $11,82 \%$
\end{tabular}


The Influence of Organizational Commitment, Competence of Village Fund Management Offficers, and Utilization of Information Technology on Accountability of Village Financial Management

\begin{tabular}{clcc} 
& Kasi of Government & 13 & $13,97 \%$ \\
& Kasi of welfare & 11 & $11,82 \%$ \\
\hline 4 & & Last Education & \\
& SLTA/SMA & 54 & $58,06 \%$ \\
& D1 & 1 & $1,07 \%$ \\
& D3 & 6 & $6,45 \%$ \\
& S1 & 32 & $34,40 \%$ \\
\hline 5 & & Work Experience (Years) & \\
& $\geq 2$ & 32 & $34,40 \%$ \\
& $3-5$ & 45 & $48,38 \%$ \\
& $>5$ & 16 & $17,20 \%$ \\
\hline
\end{tabular}

\section{Descriptive Statistical Analysis}

Table 2 Descriptive Statistics

\begin{tabular}{|c|c|c|c|c|c|}
\hline Variable & $\mathbf{N}$ & Minimum & Maximum & Mean & Std. Deviation \\
\hline $\begin{array}{l}\text { Organizational } \\
\text { Commitment (X1) }\end{array}$ & 93 & 27 & 44 & 36.86 & 3.017 \\
\hline $\begin{array}{l}\text { Competence of Village } \\
\text { Fund Officers (X2) }\end{array}$ & 93 & 24 & 40 & 31.54 & 3.497 \\
\hline $\begin{array}{l}\text { Utilization of Information } \\
\text { Technology (X3) }\end{array}$ & 93 & 27 & 40 & 33.51 & 3.027 \\
\hline $\begin{array}{l}\text { Village Financial } \\
\text { Management } \\
\text { Accountability }\end{array}$ & 93 & 30 & 50 & 42.90 & 4.157 \\
\hline Valid N (listwise) & 93 & & & & \\
\hline
\end{tabular}

\section{Data Quality Test Results}

This research uses data validity criteria i.e. when Correct Item-Total Correction and based on data, indicating all the question items of competency variables of village fund management are valid. Also all item value of the financial management accountability questionnaire variable is valid. Similarly, the reliability test in this study uses Cronbach's Alpha coefficient by comparing the Alpha $(\alpha)$ value to its standard.

Based on the reliability test results showed that the organizational commitment variable (X1) amounted to 0.732 , the competency variable of Village fund manager (X2) of 0.836 , the utilization of Information technology (X3) variable amounting to 0.782 and the village's financial Management Accountability variable (Y) of 0.899 . This shows the value of each variable greater than 0.06 which means that each variable is reliable. In addition, all research data has fulfilled the classical assumption test results.

\section{Multiple Linear Regression Analysis}

Table 3 Multiple Linear Regression Analysis

\begin{tabular}{cccc}
\hline \multirow{2}{*}{\multicolumn{2}{c}{ Model }} & \multicolumn{2}{c}{ Unstandardized Coefficients } \\
\cline { 3 - 4 } & & \multicolumn{1}{c}{ B } & Std. Error \\
\hline \multirow{4}{*}{1} & (Constant) & -255 & 3,440 \\
& X1 &, 378 &, 111 \\
& X2 &, 195 &, 090 \\
& X3 &, 689 &, 117 \\
\hline
\end{tabular}

From table 3 can be seen in the equation of double linear regression model by using SPSS which is Unstandardized Coefficients as follows.

$$
\mathrm{Y}=\alpha+\beta 1 \times 1+\beta 2 \times 2+\beta 3 \times 3+\varepsilon
$$


Where:

$$
Y=-0.255+0.378 \times 1+0.195 \times 2+0.689 \times 3+\varepsilon
$$

According to the equation of double linear regression above shows the value of constant $(\alpha)$ of -0.255 . This indicates that if there is no change in the independent variables, namely the organizational commitment (X1), the competence of the Village fund manager (X2), and the utilization of Information technology (X3), the value of accountability of the village's financial management (Y) fell by -0.255 .

Hypothesis Testing

Significance Test of Individual Parameters (t Test)

Table 4 Statistical Test Results $t$

\begin{tabular}{|c|c|c|c|c|c|c|}
\hline \multirow{2}{*}{\multicolumn{2}{|c|}{ Model }} & \multicolumn{2}{|c|}{$\begin{array}{l}\text { Unstandardized } \\
\text { Coefficients }\end{array}$} & \multirow{2}{*}{$\begin{array}{c}\begin{array}{c}\text { Standardized } \\
\text { Coefficients }\end{array} \\
\text { Beta }\end{array}$} & \multirow[t]{2}{*}{$\mathbf{T}$} & \multirow[t]{2}{*}{ Sig. } \\
\hline & & B & Std. Error & & & \\
\hline \multirow{4}{*}{1} & (Constant) & -.255 & 3.440 & & -.074 & .941 \\
\hline & $\mathrm{X} 1$ & .378 & .111 & .274 & 3.390 & .001 \\
\hline & $\mathrm{X} 2$ & .195 & .090 & .164 & 2.179 & .032 \\
\hline & $\mathrm{X} 3$ & .689 & .117 & .502 & 5.881 & .000 \\
\hline
\end{tabular}

The statistical test in table 4 indicates that the organizational commitment variables (X1) (X1) have a partial and significant impact on the village's financial management Accountability (Y). It is evidenced from the calculated tvalue of 3.390. Whereas ttable of 1.662. With significance value of 0.001 . Thus, the value of Tcounts $>$ ttable $(3.390>1.662)$ and the value of sig. $<0.05(0.001<0.05$. H2 testing showed that the competency variables of the Village fund Management apparatus (X2) have a partial and significant impact on the accountability of village (Y) finances. This is proven by value of tvalue 2.179 and the significance value of 0.032 . The result ttable of 1.662. Thus, the value of Tcounts > of ttable $(2.179>1.662)$ and the value of sig. < $0.05(0.032<0.05)$. The $\mathrm{H} 3$ test showed that the variable utilization of information technology (X3) affected partially and significantly against the accountability of village financial management (Y). It is evidenced by the calculated tvalue of 5.881. T-table result of 1.662 and sig. Value of 0.00 . Thus, thus, the value of Tcounts $>$ ttable (5.881 $>1.662)$ and the value of sig. $<0.05(0.00<0.05)$.

\section{Simultaneous Influence Test (F Test)}

Table 5 Simultaneous Test Results (Test F) ANOVA ${ }^{\mathrm{a}}$

\begin{tabular}{|c|l|c|c|c|c|c|}
\hline \multicolumn{2}{|c|}{ Model } & $\begin{array}{c}\text { Sum of } \\
\text { Squares }\end{array}$ & Df & Mean Square & F & Sig. \\
\hline \multirow{3}{*}{1} & Regression & 846,442 & 2 & 423,221 & 37,412 &, $000^{\mathrm{b}}$ \\
\cline { 2 - 8 } & Residual & 644,808 & 57 & 11,312 & & \\
\cline { 2 - 8 } & Total & 1491,250 & 59 & & & \\
\hline
\end{tabular}

a. Dependent Variable: Efektivitas Pelaksanaan Prosedur Audit Investigatif

b. Predictors: (Constant), Profesionalisme, Independensi

From these results it can be concluded that there is a significant influence between the independent variables on the dependent variables. 
The Influence of Organizational Commitment, Competence of Village Fund Management Offficers, and Utilization of Information Technology on Accountability of Village Financial Management

\section{Determination Test (R2)}

Table 6 Determination Coefficient Test Results

\begin{tabular}{lllll}
\hline Model & R & R Square & $\begin{array}{c}\text { Adjusted R } \\
\text { Square }\end{array}$ & $\begin{array}{c}\text { Std. Error of the } \\
\text { Estimate }\end{array}$ \\
\hline 1 &, $808^{\mathrm{a}}$ &, 654 &, 642 & 2,488 \\
\hline
\end{tabular}

a. Predictors: (Constant), X3, X1, X2

b. Dependent Variable: Y

Based on the results of the coefficient test (R2) known R Square Accountability of the village's financial management of 0.654 which means accountability of the village's financial management in this research can be explained by the organizational commitments, competence of village fund managers, and the utilization of information technology of $47.3 \%$ and the remainder of $52.7 \%$ explained by other factors not included in this research.

\section{Influence of organizational commitment (X1) on accountability of Village Financial Management (Y)}

The first hypothesis (H1) is the influence of the Organization's commitment to the accountability of village financial management, indicating that the organizational commitment variable is positive and significant to the accountability of village financial management. The results of this research are in line with research conducted by Mada et al (2017) stating that the Organization's commitment is a psychological tool in an organization. The results of his research showed the result of significant influence between the variables of organizational commitments to the accountability of village financial management. In addition, research conducted by Muhammad (2018) and Putri (2018) also gave the same results.

Organizational commitment is a tool of psychology in the sustainability of an organization. Organizational commitment is crucial in supporting an organization in achieving objectives. The successful management of village funds is accountable to show the commitment of the village government in organizing the financial management of village Putri (2018). The stronger the organizational commitment, the management of village funds is accountability better.

The Stewardship theory explains the form of leadership patterns and superiors ' relationships with their subordinates in an organization using situational mechanisms. The mechanisms consist of management philosophy, organizational culture and leadership to balance personal and organizational goals in order to achieve common goals.

\section{Competence influence of Village fund Management (X2) on accountability of} Village Finance (Y)

Based on the results of the test indicates that the competency variables of the village fund management apparatus (X2) are partially positive and significant towards accountability of village finances. The above test results showed that one of the factors affecting the accountability of village finance management is the competence of village fund managers. The competencies that the village fund managers have are the main requirements for accountability to run optimally. In other words, the competence of village fund management personnel can be seen from the transparency and accountability of the financial management. The more competent the village fund managers can improve the accountability of village funds management.

The attribution theory is that individual behavior is influenced by internal and external factors in the management of village funds. The Locus of Control Internal is a feeling that comes from within a person to influence its performance and behavior through its abilities, skills and efforts. Locus of Control External is a feeling that is 
controlled by factors that originate from outside the control of a person and the behavior of a person has no influence. In this case the apparatus of the village has a locus of control whether the factors that come from within itself and that are beyond the control of itself which is different from each other in the management of the village finances in accordance with the duties and responsibilities related to the competence of the village government.

\section{Effect of information technology Utilization (X3) on accountability of village Financial management (Y)}

Based on the test results indicates that a variable utilization of information technology (X3) partially influential positive and significant towards accountability of village financial management.

The results of the above test proved that one of the factors affecting the accountability of village finance management is the utilization of information technology. This research is in line with research conducted by Aulia (2018) stating that the utilization of information technology has significant effect on accountability of village fund management.

Technology Acceptance Model (TAM) is one of the theories that is very influential and is considered influential and generally used to explain the individual acceptance of the use of information technology systems. The form of acceptance can be seen with the use of information technology in the accountability of village financial management.

Influence of organizational commitment, competence of village fund managers, and utilization of information technology (X3) towards accountability of village Finance Management (Y)

Based on the test results it can be concluded that there is a significant influence between the independent variables of the dependent variable. The Stewardship theory explains the form of leadership patterns and superiors ' relationships with their subordinates in an organization using situational mechanisms to implement accountability in village financial management. Furthermore, the organizational commitment is part of the situational mechanism. In addition, the attribution theory explains that the attitudes of people taking decisions are influenced by internal and external factors. Competence of village fund managers is an internal factor and accountability of the village's financial management is an external factor, in creating accountable village financial management then it takes the utilization of good technology and ease of use for the village apparatus in accordance with the Technology Acceptance Model (TAM).

\section{Conlusion}

Based on research, the conclusion is as follows.

1. Organizational commitments positively and significantly influence the accountability of village financial management.

2. The competence of the Village fund management personnel positively and significantly affect the accountability of village finances.

3. The use of information technology has a positive and significant effect on village financial management accountability.

4. The researchers are further advised to be able to add or replace variables that can influence the accountability of village financial management and add an interview method of collecting data in order to obtain broader information from respondents. In this study there are still limited information.

5. The research instrument is the questionnaire so that it might be biased towards perceptions, the level of seriousness of respondents in answering questions and dishonesty in answering questionnaires. 
The Influence of Organizational Commitment, Competence of Village Fund Management Offficers, and Utilization of Information Technology on Accountability of Village Financial Management

\section{References}

Ainswort, M., N. Smith., \& A. Milllership. (2007). Managing Performance Managing People. Jakarta: PT. Bhuana Ilmu Populer.

Allen, N.J., \& Meyer, J. P. (1990). The measurement and antecedents of affective, continuance, and normative commitment to organization. Journal of occupational psychology, 63, 1-18.

Badan Akuntantabilitas Keuangan Negara. (2018). BAKN Dorong Evaluasi Tata Kelola Dana Desa. Jakarta : Dewan Perwakilan Rakyat RI.

Badan Pemeriksa Keuangan. (2018). BPK Dorong Pengelolaan Dana Desa Agar Efektif. Retrieved from https://keuangan.com/

Jogiyanto. (2007). Sistem Informasi Keperilakuan. Yogyakarta : Andi.

Mada, S., Kalangi, L., \& Gamaliel, H. (2017). Pengaruh Kompetensi Aparat Pengelola Dana Desa, Komitmen Organisasi Pemerintah Desa, dan Partisipasi Masyarakat terhadap Akuntabilitas Pengelolaan Dana Desa di Kabupaten Gorontalo. Tesis. Manado : Universitas Sam Ratulangi.

Mowday, R.T., Porter, L.W., \& Steers, R.M. (1982). Employee-organization linkages: The psychology of commitment, absenteeism, and turnover. New York: Academic Press.

Muhammad, R. (2018). Pengaruh Transparansi, Kompetensi dan Sistem Pengendalian Internal terhadap Akuntabilitas Pemerintah Desa Dalam Pengelolaan Alokasi Dana Desa. [Skripsi]. Pekanbaru : Universitas Riau.

Nurillah, A. S. (2014). Pengaruh Kompetensi Sumber Daya Manusia, Penerapan Sistem Akuntansi Keuangan Daerah (SAKD), Pemanfaatan Teknologi Informasi dan Sistem Pengendalian Intern terhadap Kualitas Laporan Keuangan Pemerintah Daerah (Studi Empiris Pada SKPD Kota Depok). [Skripsi]. Semarang : Universitas Diponegoro.

Pemerintah Kabupaten Luwu Timur. http://portal.luwutimurkab.go.id/index.php/en/pemerintahan/Kecamatan, diakses 16 Oktober 2019).

Putri, A (2018). Pengaruh Kompetensi Aparan Pengelola Dana Desa, Komitmen Organisasi Pemerintah Desa, Pemanfaatan Teknologi Informasi, dan Partisipasi Masyarakat Terhadap Akuntabilitas Pengelolaan Dana Desa di Kabupaten 50 Kota (Studi Empiris Pada Kecamatan Harau, Kecamatan Pangkalan Kota Baru, Dan Kecamatan Kapur IX). [Skripsi]. Pekanbaru : Universitas Riau.

Republik Indonesia. (2010). Peraturan Pemerintah Nomor 71 Tahun 2010 Tentang Standar Akuntansi Pemerintah. Jakarta : Sekretariat Negara Republik Indonesia.

Rudana, N. (2005). Pengaruh Kompetensi Aparatur PEMDA dan Komunikasi Interpersonal terhadap Kualitas Pelayanan Publik di Kantor Kabupaten Gianyar. Jurnal Ekonomi. Universitas Diponegoro.

Sakinah, N. (2013). Otonomi Daerah dan Desentralisasi Desa : Menuju Pemberdayaan Masyarakat Desa. Jurnal Politik Profetik, 1(1), 148159.(journal.uin-alauddin.ac.id/, diakses 25 Mei 2019). 
Suartana. (2010). Akuntansi Keperilakuan Teori dan Implementasinya. Yogyakarta : C.V ANDI OFFSET.

Sugiyono. (2011). Statistika untuk Penelitian. Bandung : Penerbit Alfabeta.

(2013). Metodologi Penelitian Kuantitatif, Kualitatif Dan R\&D. : Penerbit Alfabeta.

. (2014). Peraturan Menteri Dalam Negeri Nomor 32 Tahun 2006 tentang Pedoman Administrasi Desa. Jakarta: Kementerian Dalam Negeri

. (2015). Rencana Pembangunan Jangka Menengah Nasional (RPJM) 2015 2019. Jakarta: Kementerian Desa, Pembangunan Daerah Tertinggal dan Transmigrasi.

. (2018). Peraturan Menteri Dalam Negeri Nomor 20 tahun 2018 tentang Pengelolaan Keuangan Desa. Jakarta: Kementerian Dalam Negeri. 